\title{
13. A NOTE ON THE CARBON, SULFUR, AND NITROGEN CONTENTS OF HYDROTHERMALLY ALTERED SEDIMENTS, MIDDLE VALLEY, JUAN DE FUCA RIDGE ${ }^{1}$
}

\author{
Paul A. Baker ${ }^{2}$ and Scott L. Cross ${ }^{2}$
}

\begin{abstract}
Depth variations of organic and inorganic carbon, total sulfur, and total nitrogen are examined at Ocean Drilling Program Site 857 to evaluate the importance of various sedimentary and diagenetic processes to their origin. Downcore variations of organic carbon are a result of variable input rates and variable rates of turbiditic dilution. A general downcore decrease in organic carbon, particularly below the depth of the contact between sediments and the sediment-sill basement complex ( $471 \mathrm{mbsf}$ ), results from microbial and thermal organic carbon degradation and fractional mobilization. Depth variations of total nitrogen are less pronounced because of the incorporation of ammonia into diagenetic silicate minerals. Inorganic carbon varies inversely with organic carbon throughout much of the sediment column. This results from the precipitation of diagenetic carbonate cements that contain carbon partly derived from an organic carbon source. This inorganic carbon may be of remote or in-situ derivation. Most importantly, sulfur contents and sulfur isotopic compositions of sulfides increase with increasing burial depth. Whereas some fraction of this sulfur originates from early diagenetic sulfate reduction, most of it must originate from the lateral and vertical advection of dissolved sulfide from remote sites of sulfate reduction.
\end{abstract}

\section{INTRODUCTION}

One of the major goals of drilling at Middle Valley is to gain a better understanding of the influence of a thick sediment cover on the nature of hydrothermal fluid circulation and fluid composition at an oceanic spreading center. Ocean Drilling Program (ODP) Site 857 is of particular interest because it is located in a section of Middle Valley where sediment accumulation is rapid and apparently relatively continuous. Other studies published in this volume demonstrate that this site has had a simple prograde thermal history; that is, that sediments have warmed throughout their history (e.g., Davis and Wang, this volume). These factors make Site 857 a useful location for examining the influence of high heat flux on the diagenesis of a sedimentary sequence.

\section{BACKGROUND AND METHODOLOGY}

We studied two holes at Site 857 . Hole $857 \mathrm{~A}$ was hydraulically piston cored to a depth of 112.2 meters below the seafloor (mbsf). The thermal gradient measured in Hole $857 \mathrm{~A}$ was about $0.61^{\circ} \mathrm{C} / \mathrm{m}$ (Davis, Mottl, Fisher, et al., 1992). Hole $857 \mathrm{C}$ was offset by approximately $180 \mathrm{~m}$, washed down to $56.5 \mathrm{mbsf}$, and rotary drilled to a depth of 561.2 mbsf. Mafic sills interbedded with sediments were first encountered at a depth of $471 \mathrm{mbsf}$. The temperature gradient measured in the upper portion of Hole $857 \mathrm{C}$ was about $0.71^{\circ} \mathrm{C}$ (Davis, Mottl, Fisher, et al., 1992). It is assumed (e.g., Davis and Wang, this volume) that a maximum temperature of $280^{\circ} \mathrm{C}$, equivalent to the temperatures in nearby seafloor vents, is attained at the depth of the permeable basement complex (471 mbsf).

In this chapter we present and discuss measurements of sedimentary organic carbon, sedimentary inorganic carbon, total sedimentary nitrogen, and total sedimentary sulfur. In our discussion, we assume that nitrogen originates as a component of organic matter, but that it may be remineralized and incorporated into diagenetic minerals (see Whelan et al., this volume). We also assume that sulfur in these sediments is mainly present in the form of metal sulfide minerals. It is possible that some of the sulfur is also present as a sulfate salt (anhydrite, gypsum, celestite, or barite) or as an organosulfur com-

\footnotetext{
'Mottl, M.J., Davis, E.E., Fisher, A.T., and Slack, J.F. (Eds.), 1994. Proc. ODP, Sci. Results, 139: College Station, TX (Ocean Drilling Program).

${ }^{2}$ Duke University, Department of Geology, Durham, North Carolina 27708, U.S.A.
}

pound, but neither of these fractions is considered to be of quantitative importance.

Approximately 90 samples were analyzed for the same constituents aboard ship; those analyses were previously reported (Davis, Mottl, Fisher, et al., 1992, Table 15, pp. 344-345). We have analyzed an additional 97 samples in this study. Our samples were deliberately taken from finer-grained lithologies.

Measurement techniques in our study are similar to those used in the shipboard study (Davis, Mottl, Fisher, et al., 1992, p. 76). Unrinsed samples were ground and weighed into tin boats with the addition of vanadium pentoxide. Total carbon, nitrogen, and sulfur were determined by combustion, gas chromatographic separation, and thermal conductivity detection using a Carlo Erba NA 1500 CNS analyzer. Most samples were run in triplicate. The mean relative error was $1.7 \%$, $9.7 \%$, and $4.0 \%$ for carbon, nitrogen, and sulfur, respectively.

We determined inorganic carbon by leaching a separate weighed fraction of the powdered sample in buffered ammonium acetate-acetic acid ( $\mathrm{pH}=5.5$ ) for a duration of about $1 \mathrm{hr}$. An aliquot of centrifuged solution was diluted, and calcium was determined by flame atomic absorption spectrophotometry. Inorganic carbon was determined by assuming that all the dissolved calcium was originally present as $\mathrm{CaCO}_{3}$ (X-ray diffraction analyses reveal that no other carbonate minerals and no calcium sulfate salts are present in detectable quantities in these samples). This method yielded reasonable precisions (the mean relative error was $6.0 \%$ ) at low inorganic carbon contents. The shipboard inorganic carbon measurements were made coulometrically. Organic carbon was determined in both cases as the difference between total carbon and inorganic carbon. In a few samples, determined values of inorganic carbon exceeded determined values of total carbon. For these samples, organic carbon was assumed to be zero.

\section{RESULTS AND DISCUSSION}

Results of our analyses are presented in Table 1 and in Figures 1 through 7. The figures combine shipboard data from Holes 857A and $857 \mathrm{C}$ with data determined in this study. There is generally good agreement between our data and the shipboard data. Hole 857A has had a somewhat different diagenetic history than Hole $857 \mathrm{C}$ as a result of the slightly higher heat flow at Hole $857 \mathrm{C}$; nevertheless, we include the data from Hole $857 \mathrm{~A}$ in our figures to span the uncored interval at the top of Hole $857 \mathrm{C}$. 
Table 1. Inorganic carbon, organic carbon, total nitrogen, and total sulfur contents of sediments from Hole 857C.

\begin{tabular}{|c|c|c|c|c|c|c|c|c|}
\hline $\begin{array}{l}\text { Core, section, } \\
\text { interval }(\mathrm{cm})\end{array}$ & Sample & $\begin{array}{l}\text { Depth } \\
\text { (m) }\end{array}$ & $\begin{array}{l}N_{10 t} \\
(\%)\end{array}$ & $\begin{array}{l}\mathrm{C}_{\text {tot }} \\
(\%)\end{array}$ & $\begin{array}{l}S_{\mathrm{tof}} \\
(\%)\end{array}$ & $\begin{array}{c}\mathrm{CaCO}_{3} \\
(\%)\end{array}$ & $\begin{array}{c}C_{\text {inerg }} \\
(\%)\end{array}$ & $\begin{array}{l}\mathrm{C}_{\text {org }} \\
(\%)\end{array}$ \\
\hline \multicolumn{9}{|l|}{ 139-857C- } \\
\hline $2 \mathrm{R}-1,45-48$ & 139001 & 57.0 & 0.040 & 0.828 & & 3.75 & 0.46 & 0.37 \\
\hline $2 R-2,15-18$ & 139002 & 58.1 & 0.025 & 0.596 & 0.455 & 2.64 & 0.33 & 0.27 \\
\hline $3 \mathrm{R}-1,20-22$ & 139003 & 66.6 & 0.023 & 0.401 & & 0.72 & 0.09 & 0.31 \\
\hline $3 \mathrm{R}-1,37-09$ & 139004 & 66.9 & 0.044 & 0.621 & 0.096 & 2.74 & 0.34 & 0.28 \\
\hline $3 R-2,38-00$ & 139005 & 68.4 & 0.055 & 0.820 & & 3.54 & 0.44 & 0.38 \\
\hline $3 \mathrm{R}-3,12-14$ & 139006 & 69.6 & 0.048 & 0.703 & & 2.84 & 0.35 & 0.35 \\
\hline $5 R-4,26-28$ & 139008 & 82.0 & 0.037 & 0.405 & 0.112 & 1.40 & 0.17 & 0.24 \\
\hline $5 R-5,27-29$ & 139009 & 83.5 & 0.031 & 0.390 & & 0.95 & 0.12 & 0.27 \\
\hline $6 \mathrm{R}-1,43-45$ & 139011 & 86.6 & 0.061 & 0.475 & 0.097 & 0.69 & 0.09 & 0.38 \\
\hline $9 \mathrm{R}-1,46-48$ & 139015 & 115.0 & 0.035 & 0.596 & & 3.07 & 0.38 & 0.22 \\
\hline $10 \mathrm{R}-1,24-26$ & 139017 & 124.3 & 0.057 & 0.643 & & 2.19 & 0.27 & 0.37 \\
\hline $11 \mathrm{R}-1,94-96$ & 139018 & 134.7 & 0.042 & 0.620 & 0.163 & 2.74 & 0.34 & 0.28 \\
\hline $12 \mathrm{R}-1.24-28$ & 139020 & 143.7 & 0.053 & 0.827 & 0.154 & 3.98 & 0.49 & 0.34 \\
\hline $12 R-2,23-26$ & 139023 & 145.2 & 0.046 & 0.541 & & 1.52 & 0.19 & 0.35 \\
\hline $13 \mathrm{R}-1.93-95$ & 139024 & 154.0 & 0.037 & 1.702 & & & & \\
\hline $13 R-2,62-64$ & 139025 & 155.2 & 0.054 & 0.456 & 0.138 & 0.95 & 0.12 & 0.34 \\
\hline $13 \mathrm{R}-3,5-9$ & 139026 & 157.1 & 0.021 & 0.381 & & 2.76 & 0.34 & 0.04 \\
\hline $14 \mathrm{R}-2,97-99$ & 139027 & 165.3 & 0.027 & 0.655 & & 5.34 & 0.66 & 0.00 \\
\hline $15 \mathrm{R}-1,46-48$ & 139028 & 173.0 & 0.053 & 0.490 & 0.120 & 1.19 & 0.15 & 0.34 \\
\hline $15 \mathrm{R}-2,45-47$ & 139029 & 174.4 & 0.055 & 0.507 & & 0.98 & 0.12 & 0.39 \\
\hline $15 \mathrm{R}-3,35-37$ & 139030 & 175.9 & 0.055 & 0.528 & 0.062 & 1.62 & 0.20 & 0.33 \\
\hline $18 \mathrm{R}-2,26-30$ & 139032 & 203.4 & 0.054 & 0.422 & 0.107 & 0.68 & 0.08 & 0.34 \\
\hline $21 \mathrm{R}-1.44-47$ & 130034 & 231.0 & & & & 0.51 & 0.06 & \\
\hline $21 \mathrm{R}-2,48-50$ & 139035 & 232.6 & 0.045 & 0.371 & 0.042 & 0.56 & 0.07 & 0.30 \\
\hline $21 \mathrm{R}-3,74-77$ & 139036 & 234.3 & & & & 0.81 & 0.10 & \\
\hline $24 \mathrm{R}-1,31-35$ & 139039 & 259.5 & & & & 0.85 & 0.10 & \\
\hline $24 \mathrm{R}-2.8-10$ & 139040 & 260.8 & 0.049 & 0.495 & 0.268 & 0.63 & 0.08 & 0.42 \\
\hline $25 \mathrm{R}-1,41-43$ & 139041 & 269.2 & & & & 0.56 & 0.07 & \\
\hline $25 \mathrm{R}-1,41-43$ & 139041 & 269.2 & & & & 0.88 & 0.11 & \\
\hline $26 \mathrm{R}-1,14-16$ & 139042 & 274.6 & & & & 0.96 & 0.12 & \\
\hline $27 \mathrm{R}-1,41-45$ & 139044 & 284.5 & & & & 0.53 & 0.07 & \\
\hline 28R-1, 87-89 & 139045 & 294.7 & 0.046 & 0.393 & 0.076 & 0.91 & 0.11 & 0.28 \\
\hline $28 \mathrm{R}-2,69-71$ & 139046 & 296.0 & & & & 1.20 & 0.15 & \\
\hline $28 \mathrm{R}-3,45-47$ & 139047 & 297.2 & & & & 1.60 & 0.20 & \\
\hline $29 \mathrm{R}-1,78-80$ & 139048 & 304.2 & & & & 0.29 & 0.04 & \\
\hline $29 \mathrm{R}-2,52-54$ & 139049 & 305.4 & & & & 1.27 & 0.16 & \\
\hline $30 \mathrm{R}-1,36-38$ & 139050 & 313.5 & 0.023 & 0.435 & & 2.46 & 0.30 & 0.13 \\
\hline $30 \mathrm{R}-2,46-49$ & 139051 & 315.1 & 0.039 & 0.491 & 0.365 & & & \\
\hline $30 \mathrm{R}-3,90-94$ & 139052 & 317.0 & 0.064 & 0.477 & 0.132 & 0.59 & 0.07 & 0.41 \\
\hline $31 \mathrm{R}-1,45-47$ & 139053 & 323.2 & 0.058 & 0.358 & & 0.75 & 0.09 & 0.27 \\
\hline $31 \mathrm{R}-2,38-40$ & 139054 & 324.6 & 0.066 & 0.463 & 0.201 & 0.77 & 0.10 & 0.36 \\
\hline $32 \mathrm{R}-1,44-47$ & 139055 & 328.0 & 0.053 & 0.382 & 0.095 & 0.47 & 0.06 & 0.32 \\
\hline $32 R-2,87-89$ & 139056 & 330.0 & 0.053 & 0.349 & & 1.22 & 0.15 & 0.20 \\
\hline $32 \mathrm{R}-3,45-47$ & 139057 & 331.0 & 0.070 & 0.337 & 0.037 & 0.43 & 0.05 & 0.29 \\
\hline $33 \mathrm{R}-1,20-23$ & 139058 & 332.6 & 0.010 & 0.353 & & 1.07 & 0.13 & 0.22 \\
\hline $33 \mathrm{R}-2,27-29$ & 139059 & 334.2 & 0.025 & 0.461 & 0.143 & 2.33 & 0.29 & 0.17 \\
\hline $33 \mathrm{R}-3,29-31$ & 139060 & 335.7 & 0.033 & 0.487 & 0.174 & 2.51 & 0.31 & 0.18 \\
\hline
\end{tabular}

Organic carbon (Fig. 1) is highest in near-surface, hemipelagic sediments and decreases with increasing burial depth to an apparent minimum around 200 mbsf. Higher values are observed in the dark gray (N4/) silty claystones that predominate near $350 \mathrm{mbsf}$.

Finally, a dramatic decrease is found in the lowest section of the sediment column and in sediments interbedded with sills. This decrease was noted previously (Davis, Mottl, Fisher, et al., 1992, p. 326), although our data suggest that the decrease actually occurs well above the depth of the first sill at 471 mbsf.

Inorganic carbon (Fig. 2) is variable, but is relatively high in the upper $100 \mathrm{~m}$ of sediment. It decreases with increasing depth to an apparent minimum around $250 \mathrm{mbsf}$, increases to maximum values between 350 and $400 \mathrm{mbsf}$, and plummets to lower values at greater depths. The mid-depth maximum is manifested by abundant carbonate cement and by unusually good preservation of calcareous microfossils (Davis, Mottl, Fisher, et al., 1992, pp. 300 and 303). This maximum can reasonably be explained as a change in the original content of inorganic carbon in the sediments reaching the seafloor. Because the observed values closely resemble those in sediments from the Holocene and Interglacial Stage 5 (approximately $40 \mathrm{mbsf}$, Brunner, this volume), we propose that the interval from 350 to 400 mbsf represents Interglacial Stage 7 (approximately 200 to $250 \mathrm{Ka}$; Morley and Hays, 1981).

Total nitrogen (Fig. 3) shows little apparent systematic variation with burial depth. The exponential decrease of nitrogen with depth near the top of Hole 857C, cited in Davis, Mottl, Fisher, et al. (1992, p. 326), is not borne out by our work. The average molar ratio of

\begin{tabular}{|c|c|c|c|c|c|c|c|c|}
\hline $\begin{array}{l}\text { Core, section, } \\
\text { interval }(\mathrm{cm})\end{array}$ & Sample & $\begin{array}{l}\text { Depth } \\
\text { (m) }\end{array}$ & $\begin{array}{l}\mathrm{N}_{\text {tor }} \\
(\%)\end{array}$ & $\begin{array}{l}\mathrm{C}_{i o t} \\
(\%)\end{array}$ & $\begin{array}{l}\mathrm{S}_{\text {tor }} \\
(\%)\end{array}$ & $\begin{array}{c}\mathrm{CaCO}_{3} \\
(\%)\end{array}$ & $\begin{array}{c}\mathrm{C}_{\text {inotg }} \\
(\%)\end{array}$ & $\begin{array}{l}\mathrm{C}_{\text {org }} \\
(\%)\end{array}$ \\
\hline $34 \mathrm{R}-1,32-34$ & 139061 & 336.8 & 0.051 & 0.612 & & 2.95 & 0.36 & 0.25 \\
\hline $34 \mathrm{R}-2,28-31$ & 139062 & 338.3 & 0.051 & 0.674 & & 3.45 & 0.43 & 0.24 \\
\hline $34 \mathrm{R}-3,28-30$ & 139063 & 339.8 & 0.044 & 0.514 & 0.331 & 2.48 & 0.31 & 0.20 \\
\hline $35 \mathrm{R}-1,76-79$ & 139064 & 342.1 & 0.071 & 0.770 & 0.185 & 1.16 & 0.14 & 0.63 \\
\hline $35 \mathrm{R}-3,64-66$ & 139065 & 344.9 & 0.075 & 0.454 & 0.191 & 0.67 & 0.08 & 0.37 \\
\hline $36 \mathrm{R}-1,60-62$ & 139066 & 346.7 & 0.079 & 0.359 & & 0.76 & 0.09 & 0.27 \\
\hline $36 \mathrm{R}-2,35-37$ & 139067 & 347.9 & 0.081 & 0.483 & 0.126 & 1.44 & 0.18 & 0.30 \\
\hline $36 \mathrm{R}-2,61-63$ & 139068 & 348.2 & 0.062 & 0.448 & & 1.59 & 0.20 & 0.25 \\
\hline $36 \mathrm{R}-3,68-71$ & 139069 & 349.8 & 0.065 & 0.347 & 0.057 & 0.96 & 0.12 & 0.23 \\
\hline $37 \mathrm{R}-1,44-46$ & 139070 & 351.2 & 0.054 & 0.654 & 0.083 & 3.42 & 0.42 & 0.23 \\
\hline $37 \mathrm{R}-3,21-25$ & 139072 & 354.0 & 0.069 & 0.753 & & 2.69 & 0.33 & 0.42 \\
\hline $38 \mathrm{R}-1,18-20$ & 139073 & 356.0 & 0.038 & 0.493 & 0.303 & 1.28 & 0.16 & 0.33 \\
\hline $38 \mathrm{R}-2,42-44$ & 139074 & 357.7 & 0.029 & 0.424 & & 2.52 & 0.31 & 0.11 \\
\hline $39 \mathrm{R}-2,32-34$ & 139076 & 362.2 & 0.031 & 4.831 & 0.153 & & & \\
\hline $39 \mathrm{R}-2,128-130$ & 139078 & 363.2 & 0.052 & 0.521 & 0.213 & 1.94 & 0.24 & 0.28 \\
\hline $39 \mathrm{R}-3,36-38$ & 139079 & 363.8 & 0.074 & 1.258 & & 7.97 & 0.98 & 0.28 \\
\hline $40 \mathrm{R}-1,114-116$ & 139080 & 366.5 & 0.025 & 0.509 & & 4.35 & 0.54 & -0.03 \\
\hline $40 \mathrm{R}-2,78-80$ & 139081 & 367.7 & 0.049 & 0.815 & 0.778 & 4.87 & 0.60 & 0.21 \\
\hline $41 \mathrm{R}-1,18-20$ & 139082 & 375.1 & 0.051 & 0.557 & 0.205 & 2.86 & 0.35 & 0.21 \\
\hline $41 \mathrm{R}-2,55-59$ & 139083 & 377.0 & & & & 2.93 & 0.36 & -0.36 \\
\hline $41 R-3,50-52$ & 139084 & 378.4 & 0.046 & 0.486 & 0.175 & 2.10 & 0.26 & 0.23 \\
\hline $42 \mathrm{R}-1,78-80$ & 139085 & 380.5 & 0.038 & 0.463 & & 1.11 & 0.14 & 0.32 \\
\hline $42 \mathrm{R}-2,47-49$ & 139086 & 381.7 & 0.053 & 0.474 & 0.153 & 1.65 & 0.20 & 0.27 \\
\hline $43 \mathrm{R}-1,53-55$ & 139087 & 385.2 & 0.060 & 0.538 & 0.184 & 0.96 & 0.12 & 0.42 \\
\hline $43 R-2,60-62$ & 139088 & 386.8 & 0.064 & 0.598 & 0.190 & 1.47 & 0.18 & 0.42 \\
\hline $43 R-3,60-64$ & 139089 & 388.3 & 0.063 & 0.490 & 0.233 & 0.81 & 0.10 & 0.39 \\
\hline $44 \mathrm{R}-2,21-25$ & 139090 & 391.4 & 0.048 & 0.474 & & 1.07 & 0.13 & 0.34 \\
\hline $44 R-2,39-42$ & 139091 & 391.6 & 0.034 & 0.545 & 0.226 & 2.88 & 0.36 & 0.19 \\
\hline $45 \mathrm{R}-1,81-84$ & 139092 & 395.1 & 0.008 & 0.568 & & 3.87 & 0.48 & 0.09 \\
\hline $45 \mathrm{R}-1,128-130$ & 139093 & 395.6 & 0.052 & 0.739 & & 4.13 & 0.51 & 0.23 \\
\hline $45 R-2,65-67$ & 139094 & 396.4 & 0.052 & 0.451 & 0.134 & 1.85 & 0.23 & 0.22 \\
\hline $46 \mathrm{R}-1,107-109$ & 139095 & 400.1 & 0.023 & 0.511 & & 3.09 & 0.38 & 0.13 \\
\hline $46 \mathrm{R}-2,19-21$ & 139096 & 400.7 & 0.073 & 0.547 & & 1.45 & 0.18 & 0.37 \\
\hline $47 \mathrm{R}-1,83-85$ & 139097 & 404.8 & 0.040 & 0.556 & 0.255 & 4.08 & 0.50 & 0.06 \\
\hline $48 \mathrm{R}-1,40-42$ & 139098 & 409.1 & 0.000 & 0.556 & & 0.89 & 0.11 & 0.45 \\
\hline $48 \mathrm{R}-1,103-105$ & 139099 & 409.7 & 0.065 & 0.523 & & 0.94 & 0.12 & 0.40 \\
\hline $48 \mathrm{R}-2,60-61$ & 139100 & 410.8 & 0.013 & 0.573 & 0.212 & 5.33 & 0.66 & -0.09 \\
\hline $48 \mathrm{R}-2,114-116$ & 139101 & 411.3 & 0.071 & 0.474 & & 0.21 & 0.03 & 0.44 \\
\hline $49 \mathrm{R}-1,44-46$ & 139102 & 414.1 & 0.052 & 0.490 & 0.122 & 1.11 & 0.14 & 0.35 \\
\hline $49 R-2,100-102$ & 139103 & 416.2 & 0.058 & 0.462 & & 1.65 & 0.20 & 0.26 \\
\hline $50 \mathrm{R}-1,102-105$ & 139104 & 419.3 & 0.000 & 0.512 & & 0.79 & 0.10 & 0.41 \\
\hline $51 R-1,39-43$ & 139105 & 423.8 & 0.034 & 0.408 & 0.199 & 0.96 & 0.12 & 0.29 \\
\hline $52 \mathrm{R}-1,117-119$ & 139106 & 429.0 & 0.069 & 0.455 & & 0.43 & 0.05 & 0.41 \\
\hline $52 \mathrm{R}-2,20-22$ & 139107 & 429.5 & 0.046 & 0.406 & & 0.32 & 0.04 & 0.37 \\
\hline $53 R-1,31-33$ & 139108 & 433.1 & 0.046 & 0.417 & 0.157 & 0.55 & 0.07 & 0.35 \\
\hline $56 R-1,3-4$ & 139109 & 446.5 & 0.030 & 0.469 & & 0.14 & 0.02 & 0.45 \\
\hline $57 R-1,20-21$ & 139110 & 451.9 & 0.000 & 0.108 & 0.431 & 0.13 & 0.02 & 0.09 \\
\hline 58R-1. 14-15 & 139111 & 461.6 & 0.011 & 0.366 & & 0.10 & 0.01 & 0.36 \\
\hline
\end{tabular}

organic carbon to total nitrogen is about 7.6, surprisingly close to the Redfield ratio of 7.0. The observed ratio tends to decrease with increasing burial depth below about $350 \mathrm{mbsf}$. This may be a reflection of the thermal degradation of organic matter downhole (decreasing organic carbon) and the incorporation of ammonia into diagenetic mineral phases (see Whelan et al., this volume).

Total sulfur (Fig. 4) is highly variable in near-surface sediments, is relatively low over an intermediate depth range, but increases rather systematically with increasing burial depth below $100 \mathrm{mbsf}$. This increase is significant in all the data from Hole 857C ( $\mathrm{r}=0.261, \mathrm{n}=$ 100 , significant at the 0.01 level). Total sulfur shows no systematic relationship with sedimentary organic carbon content (Fig. 5). In Hole $857 \mathrm{C}$ there is a tendency $(\mathrm{r}=0.209, \mathrm{n}=100$, significant at the 0.05 level) for the ratio (organic carbon)/(total sulfur) to decrease with increasing burial depth (Fig. 6).

The diagenetic reaction of most interest to this study, because it links the chemistry of carbon and sulfur, is sulfate reduction, simply written:

$$
2 \mathrm{CH}_{2} \mathrm{O}+\mathrm{SO}_{4}^{2-}=2 \mathrm{HCO}_{3}^{-}+\mathrm{H}_{2} \mathrm{~S} \text {. }
$$

This reaction may be microbially mediated up to about $100^{\circ} \mathrm{C}$ (Brock and Madigan, 1991) or thermally catalyzed (abiogenically) at temperatures greater than $100^{\circ} \mathrm{C}$ (e.g., Krouse et al., 1988). The reaction has many consequences for diagenesis, including the following: (1) It is one of the two most important reactions for oxidation of organic matter in marine sediments (e.g., Jorgensen, 1982). (2) For every mole 


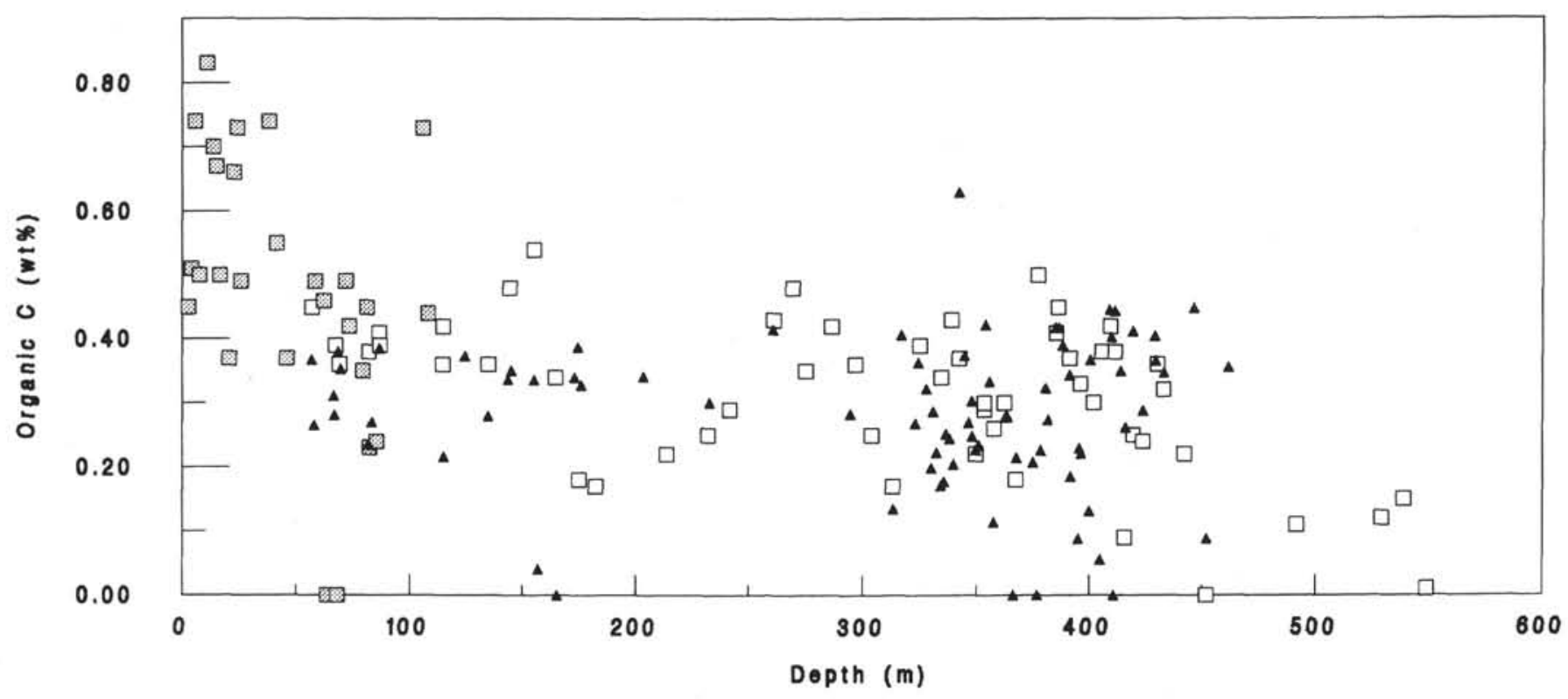

Figure 1. Organic carbon contents vs. burial depth (mbsf) for all samples from Holes 857A and 857C. Open squares represent previously published data from Hole 857C; squares represent previously published data from Hole 857A; triangles represent new data from the present study.

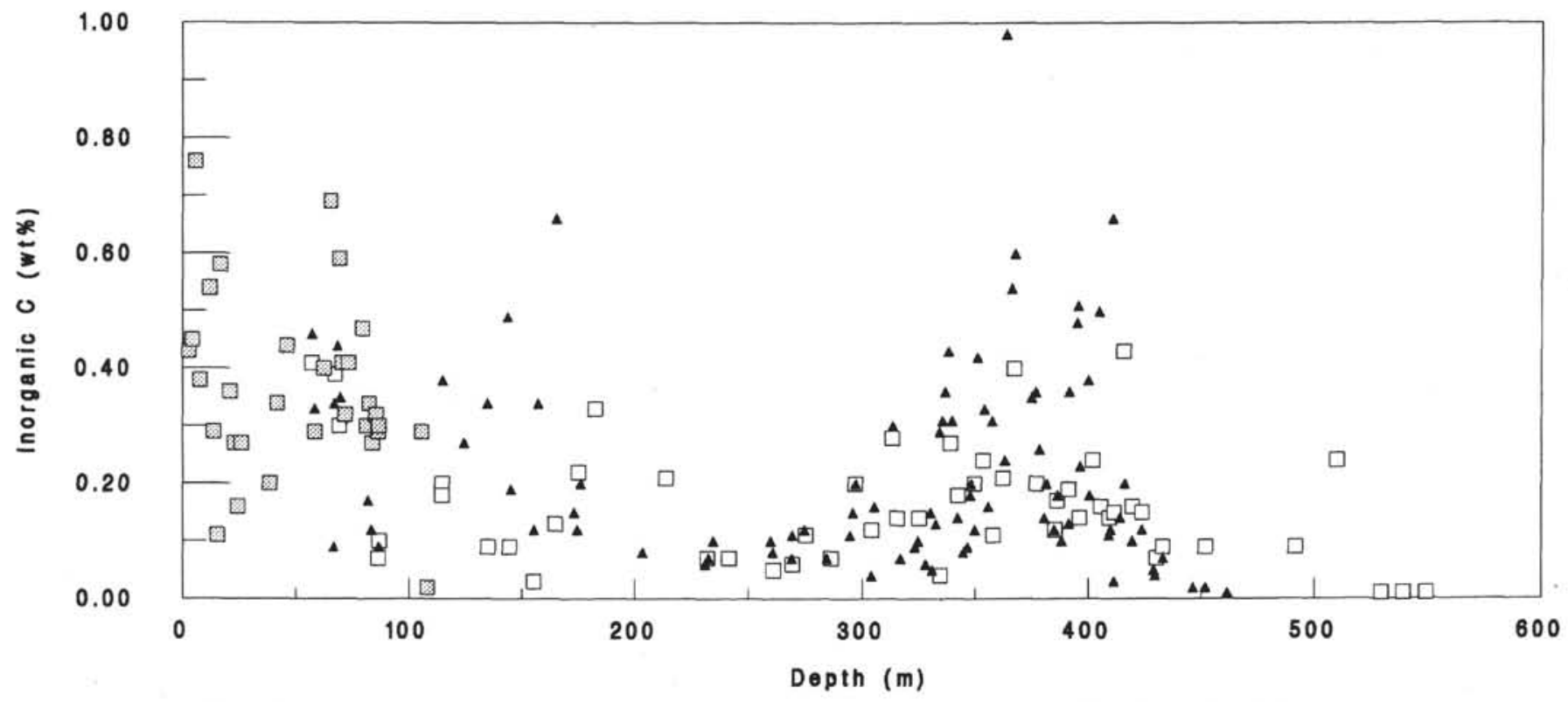

Figure 2. Inorganic carbon contents vs. burial depth for all samples from Holes $857 \mathrm{~A}$ and $857 \mathrm{C}$. Symbols as in Figure 1.

of organic carbon oxidized, one-half mole of sulfide is produced and dominantly precipitated as pyrite. Thus, in many marine sediments there is a correlation between organic carbon and pyrite-sulfur contents (e.g., Berner and Raiswell, 1983). (3) The dissolved carbon dioxide resulting from organic carbon oxidation may be incorporated into diagenetic carbonates with distinctive stable carbon isotopic compositions (e.g., Baker et al., this volume).

Under some circumstances, methane (or other short-chained hydrocarbon compounds) may serve as the reduced carbon source (e.g., Alperin and Reeburgh, 1984):

$$
\mathrm{CH}_{4}+\mathrm{SO}_{4}^{2-}=\mathrm{HCO}_{3}^{-}+\mathrm{HS}^{-}+\mathrm{H}_{2} \mathrm{O} \text {, }
$$

and sulfate reduction can result even when the in-situ organic matter is not readily metabolizable. Likewise, solid sulfate salts such as anhydrite can serve as a sedimentary source of oxidized sulfur if dissolved sulfate is depleted.

Reasonable interpretations for the downhole increase of sulfur observed in Hole 857C (Fig. 4) are (1) addition of sulfur to the sediments occurred during deep burial, (2) the amount of early diagenetic sulfide formed in shallow sediments by microbial sulfate reduction decreased through time or, (3) the amount of dilutant sediment reaching the seafloor increased through time (that is, early sulfide formation rates remained constant but sedimentation rates increased). Because it is likely in these organic-lean sediments that pyrite formation is subject to the limited availability of metabolizable organic matter (rather than the availability of labile iron or of dissolved sulfate), interpretation (2) would require a decrease through time in the input of organic carbon to the sediments. Although we favor the first interpretation, the addition of sulfur to the sediments during deep burial cannot be due to 


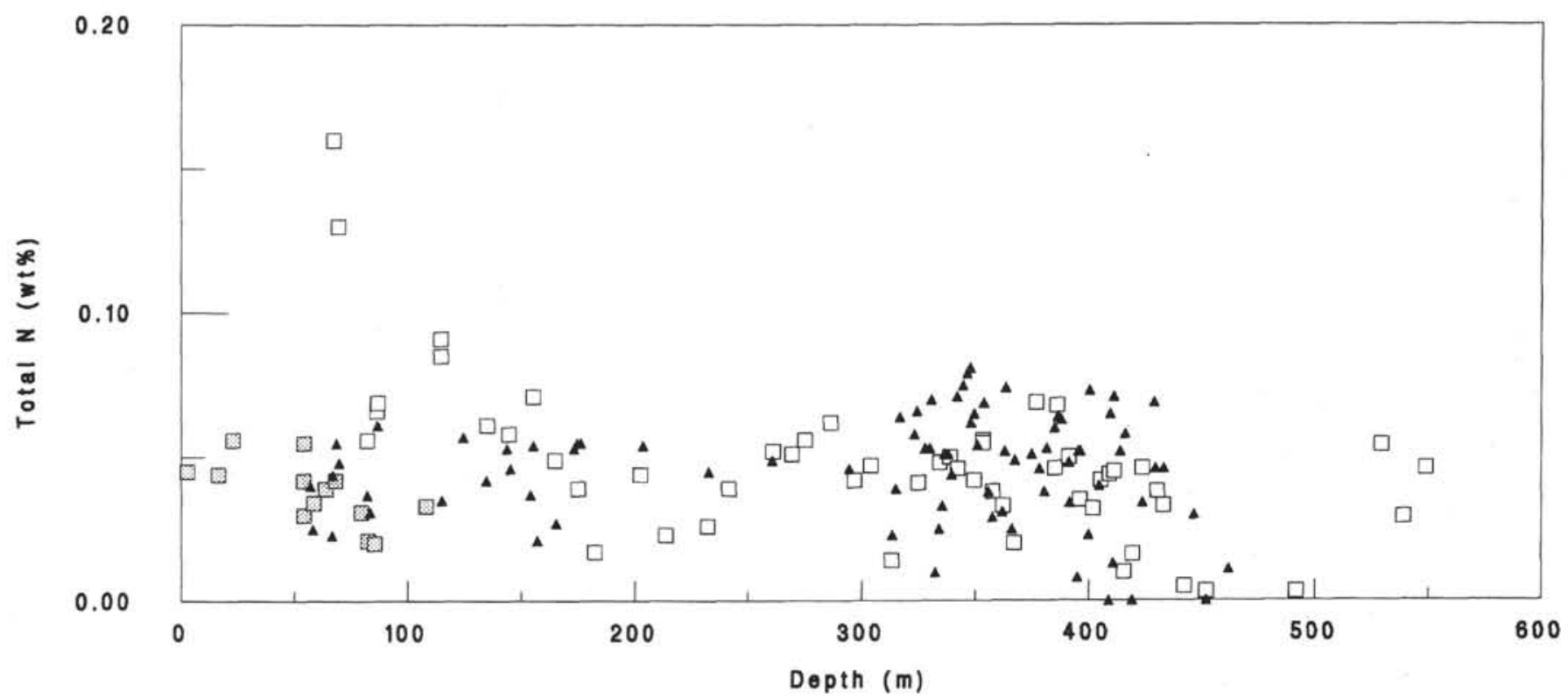

Figure 3. Total nitrogen contents vs. burial depth for all samples from Holes $857 \mathrm{~A}$ and $857 \mathrm{C}$. Symbols as in Figure 1.

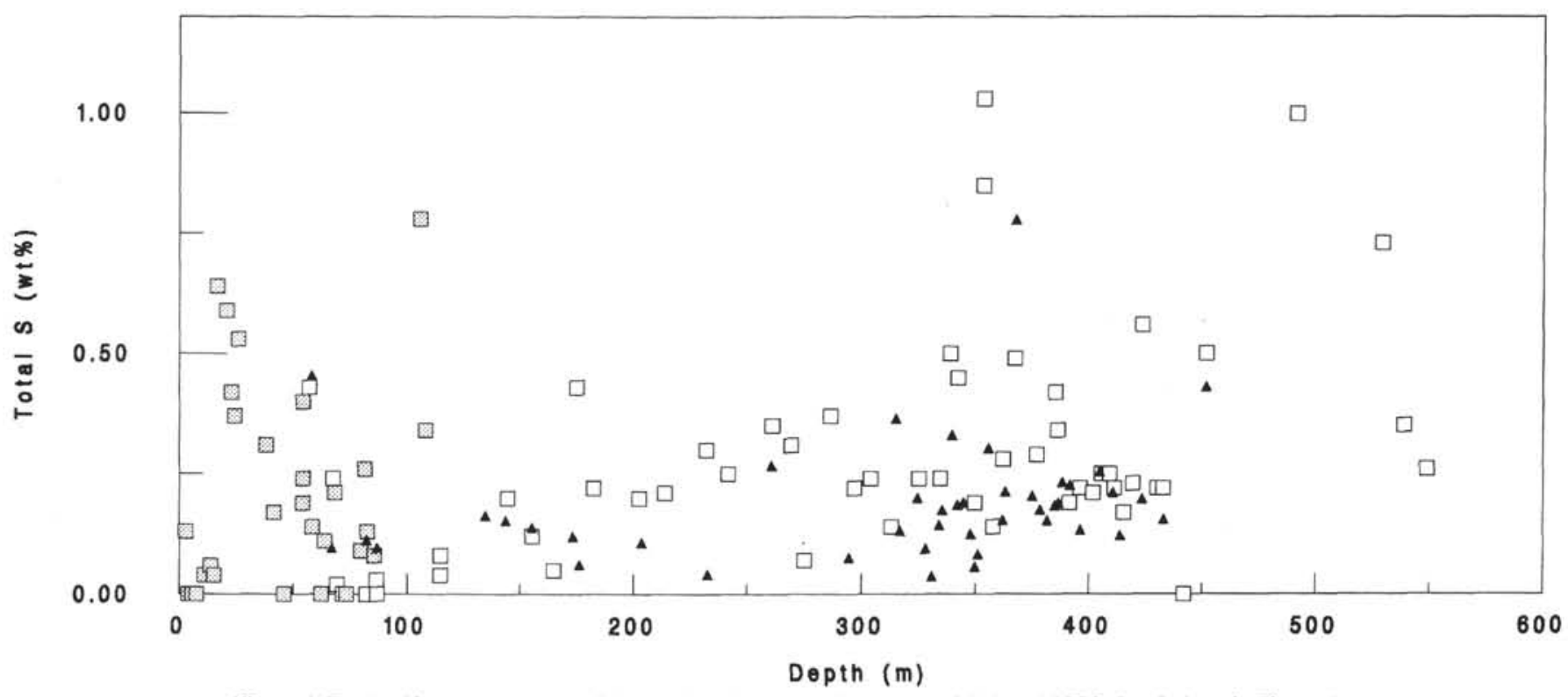

Figure 4. Total sulfur contents vs. burial depth for all samples from Holes 857A and 857C. Symbols as in Figure 1.

steady-state, in-situ sulfate reduction processes, as present-day dissolved sulfate concentration gradients (Davis, Mottl, Fisher, et al., 1992, p. 334) indicate that sulfate reduction rates below a few meters below seafloor are two orders of magnitude too slow to account for the observed increase. Furthermore, anhydrite and barite have only been observed to occur (in minor abundance) over a depth range of about 70 to 150 mbsf (Davis, Mottl, Fisher, et al., 1992, p. 298), so they cannot be called on to affect deeper processes. Rather, we believe that the downhole addition of sulfur is caused by sulfate reduction at a remote setting and the import of dissolved sulfide by interstitial fluids advecting laterally through the permeable sill-sediment basement complex and advecting vertically through faults, fractures, and small-scale burrows (see Rigsby et al., this volume). One important aspect of this scenario is the physical separation of the site(s) of sulfate reduction and organic carbon oxidation from the site of sulfide precipitation. Such a system, operating on a grander scale, may have been responsible for the formation of the massive sulfide body penetrated by Holes $856 \mathrm{G}$ and $856 \mathrm{H}$. The strongest evidence in favor of this interpretation is the sulfur isotopic data presented by Zierenberg (this volume). At Site 857 he observed negative sulfur isotopic values in pyrites from shallow burial depths (less than $70 \mathrm{mbsf}$ ) and a progressive increase in sulfur isotopic values to an average of $\delta^{34} \mathrm{~S}=$ +9.3\% below $471 \mathrm{mbsf}$ (the sediment/basement contact).

A significant inverse correlation exists between inorganic-carbon and organic-carbon contents of the sediments in Hole 857C (Fig. 7, $\mathrm{r}=0.455, \mathrm{n}=127$, significant at the 0.01 level). Most exceptions are samples from shallow depths (organic carbon- and inorganic carbonrich hemipelagic sediments of Holocene age) and samples from basement (organic carbon- and inorganic carbon-poor sediments that have been strongly heated during hydrothermal alteration). Stable isotopic data indicate that over one-half of the carbon in calcites from Hole $857 \mathrm{C}$ is of organic origin (Baker et al., this volume). On average, these 


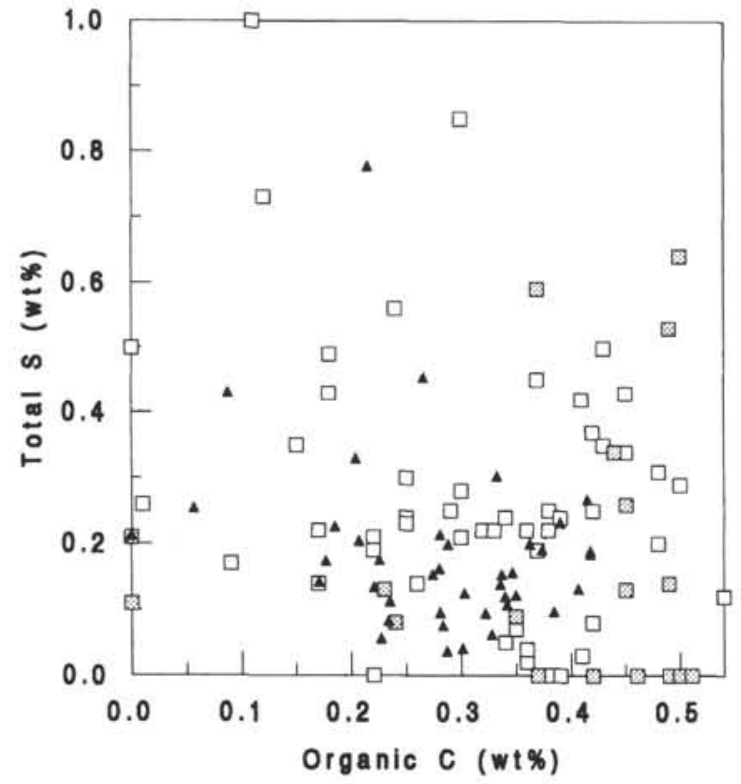

Figure 5. Total sulfur contents vs, organic carbon contents for all samples from Holes $857 \mathrm{~A}$ and $857 \mathrm{C}$. Symbols as in Figure 1.

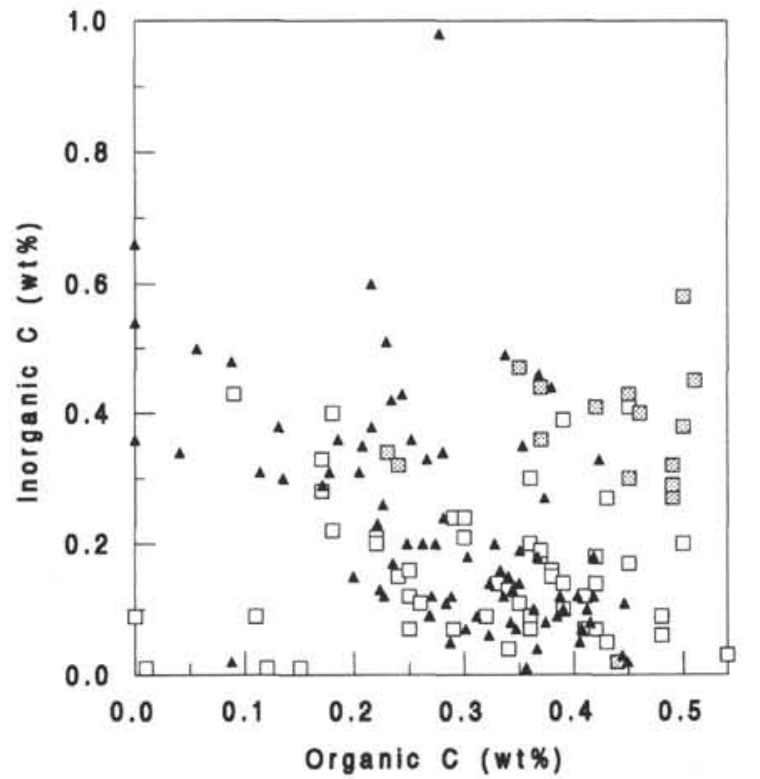

Figure 7. Inorganic carbon contents vs. organic carbon contents for all samples from Holes 857A and 857C. Symbols as in Figure 1.

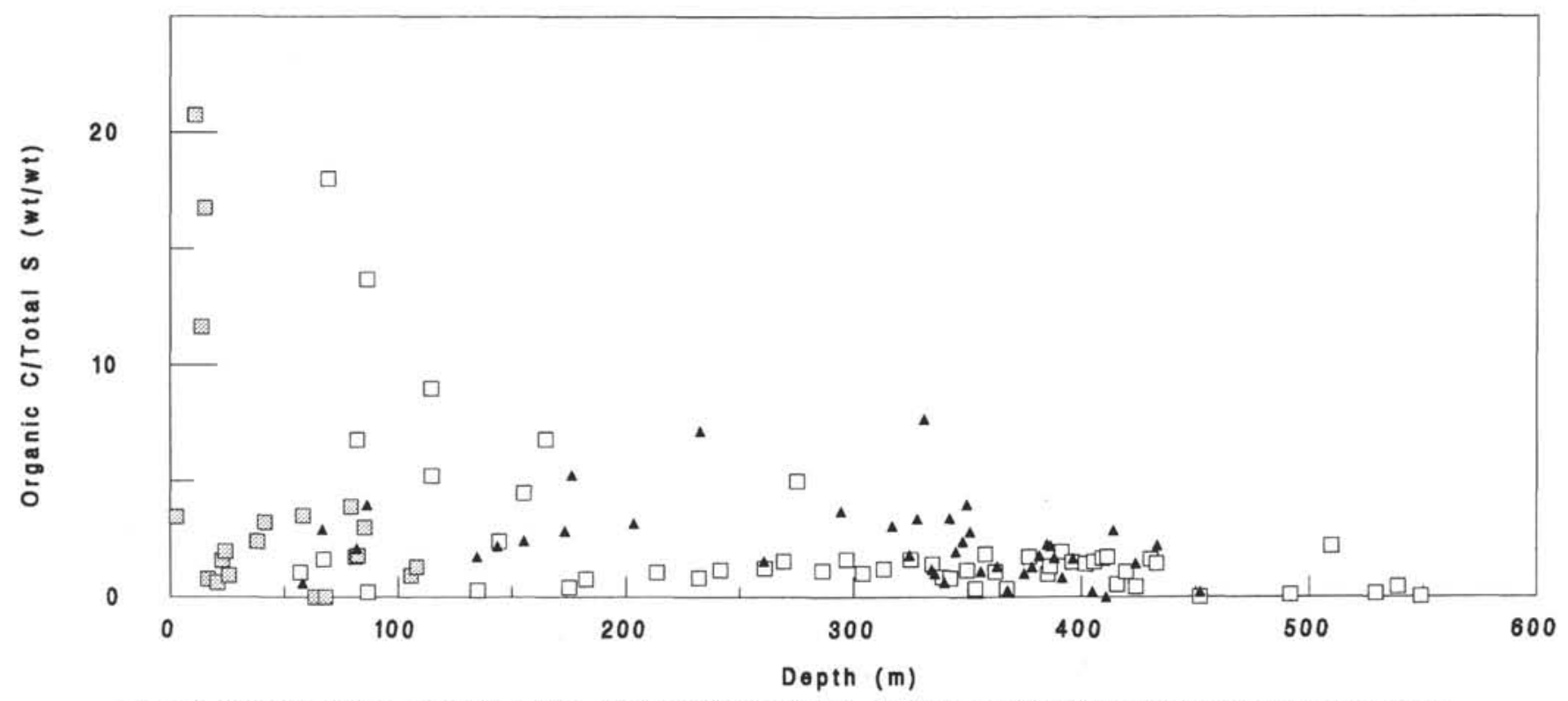

Figure 6. Organic carbon-to-total sulfur weight ratio vs. burial depth for all samples from Holes 857A and 857C. Symbols as in Figure 1.

sediments contain about 0.15 weight percent (wt\%) inorganic carbon. Assuming that half is of organic origin formed by oxidation during sulfate reduction, we calculate from the stoichiometry of sulfate reduction assumed above that as much as $0.20 \mathrm{wt} \%$ of sulfide-sulfur was produced by sulfate reduction (assuming quantitative precipitation). Because this is close to the observed average sulfur content of the sediments, it is likely that in-situ sulfate reduction near the sediment-water interface also played an important role in the origin of some fraction of the sedimentary sulfides.

\section{CONCLUSIONS}

1. Organic carbon contents of the sediments at Site 857 vary as a result of variable sedimentary input rate and turbiditic dilution rate, microbially-mediated reactions, and thermal degradation.
2. Inorganic carbon contents vary as a result of variable sedimentary input rates and turbiditic dilution rates. Highest carbonate contents are found in fine-grained intervals, possibly deposited in interglacial Stages 1, 5, and 7. About half of the carbonate found in sediments below 100 mbsf is of organic-carbon origin, having formed as a result of in-situ or remote sulfate reduction or thermocatalytic decarboxylation.

3. The sulfur contents of the sediments, although of probable sulfate-reduction origin, show little systematic relationship with associated organic carbon contents. The sulfur contents and the sulfur isotopic compositions of the sulfides (Zierenberg, this volume) increase with burial depth. This is interpreted to result from sulfate reduction at remote sites and the import of dissolved sulfide to the sediments from hydrothermal fluids advecting through basement. The locus of the sulfate reduction and the pathways that sulfide-bearing fluids follow to this site are important, still unsolved, problems. 


\section{ACKNOWLEDGMENTS}

This work would not have been possible without the help of the entire crew and scientific party of the JOIDES Resolution. We also thank the shore-based personnel at ODP in College Station for their efforts on our behalf. This paper has benefitted from the reviews of Mike Mottl, John Morse, the ODP editorial staff, and an anonymous reviewer. Funding for this work was provided by JOI/USSSP.

\section{REFERENCES $*$}

Alperin, M.J., and Reeburgh, W.S., 1984. Geochemical observations supporting anaerobic methane oxidation. In Crawford, R.L., and Hanson, R.S. (Eds.), Microbial Growth on C-1 Compounds. Am. Soc. Microbiol., 282-298.

Berner, R.A., and Raiswell, R., 1983. Burial of organic carbon and pyrite sulfur in sediments over Phanerozoic time: a new theory. Geochim. Cosmochim. Acta, 47:855-862.

Brock, T.D., and Madigan, M.T., 1991. Biology of Microorganisms (6th ed.): Englewood Cliffs, NJ (Prentice-Hall).
Davis, E.E., Mottl, M.J., Fisher, A.T., et al., 1992. Proc. ODP, Init. Repts., 139: College Station, TX (Ocean Drilling Program).

Jørgensen, B.B., 1982. Mineralization of organic matter in the seabed-the role of sulphate reduction. Nature, 296:643-645.

Krouse, H.R., Viau, C.A., Elink, L.S., Ueda, A., and Halas, S., 1988. Chemical and isotopic evidence of thermochemical sulphate reduction by light hydrocarbon gases in deep carbonate reservoirs. Nature, 333:415-519.

Morley, J.J., and Hays, J.D., 1981. Towards a high-resolution, global, deep-sea chronology for the last 750,000 years. Earth Planet. Sci. Lett., 53:279-295.

Abbreviations for names of organizations and publications in ODP reference lists follow
the style given in Chemical Abstracts Service Source Index (published by American the style given in $C$
Chemical Society).

Date of initial receipt: 12 March 1993

Date of acceptance: 28 September 1993

Ms 139SR-214 